\title{
Improvement in volitional tests of muscle function alone may not be adequate evidence that inspiratory muscle training is effective
}

\author{
M.I. Polkey*, J. Moxham ${ }^{\#}$
}

In 1976 LEITH and BRADLEY [1] generated the hypothesis that the inspiratory muscles, like other muscles, could be trained. In the now classic study 12 healthy adults were divided into three groups of four. One group underwent strength testing, consisting of maximal voluntary efforts against a closed airway over a range of lung volumes for 30 min per day for 5 days a week for 5 weeks. The second group performed voluntary hyperventilation for a similar period and the third group served as controls. They found that subjects undergoing strength training increased strength by $55 \%$ while endurance trainers experienced a $15-19 \%$ increase in the time that they could sustain maximal and submaximal ventilation. Only minor improvements were seen in control subjects. Since the seminal observations of LEITH and BRADLEY [1] numerous investigators (a PubMed search with the term respiratory muscle training yielded over 1500 citations in September 2003) have explored the field, yet the clinical role of inspiratory muscle training remains controversial.

In high income countries chronic obstructive pulmonary disease (COPD) is the most prevalent respiratory disability of adults [2]. The maximal static inspiratory pressure $(P I, \max )$ is often reduced in patients with COPD $[3,4]$ and it is therefore unsurprising that various groups have sought to evaluate respiratory muscle training for such patients. However in the light of recent insights into diaphragm function in COPD the validity of this approach is not clear-cut. First, although $P I$ max is reduced this is mainly because of hyperinflation; when hyperinflation is discounted then in vivo diaphragm function is normal [5] or enhanced [6] in COPD. Second, despite early data on fatigue based on electromyographic studies, low frequency diaphragm fatigue is not associated with exercise intolerance [7, 8] or respiratory failure [9] in patients with COPD. Indeed the in vivo impression of fatigue resistance of the diaphragm in patients with COPD has been confirmed by the demonstration of cellular adaptations of this muscle in patients [10-13]. In addition, before recommending such treatment to patients, one would also want evidence that inspiratory muscle training improves the contractile properties of the diaphragm. As far as the current authors are aware only one small study [14], from the present authors laboratory, has attempted to assess diaphragm contractility using phrenic nerve stimulation and, despite an improvement in $P I$,max the current authors were unable to detect any improvement in twitch transdiaphragmatic pressure. How did $P \mathrm{I}$,max increase without improvement in diaphragm function; one answer could be because the subjects get better at "doing the test". Certainly PI,max has been shown to increase substantially as a result of placebo treatment; for example SCHERER et al. [15] found a $17.5 \%$ increase in PI,max in COPD patients allocated to control training. A biological explanation for this learning effect has recently emerged with the demonstration that the excitability of the area of the motor cortex representing the diaphragm can be increased by a course of inspiratory muscle training [16].

Our view is that studies evaluating inspiratory muscle training are most valuable when the outcome measure is both functionally worthwhile and also unrelated to the training modality. Additionally a placebo that seems plausible from the patients' perspective is recommended. In COPD the most useful outcome measure is likely to be exercise performance evaluated using a validated field test.

Against this background a review of studies in patients with COPD was recently reported in the European Respiratory Journal $(E R J)$ by LOTTERS et al. [17]; only 15 were deemed worthwhile submitting to meta-analysis. When these studies were considered no significant effect of inspiratory muscle training was found for either $P \mathrm{I}$,max or for indices of walking ability. LOTTERS et al. [17] then divided the patients studied according to whether there was pre-existing inspiratory muscle weakness. Even so there was no statistically significant benefit for walking distance though there was for PI,max itself. This latter finding should be interpreted with caution however because of the tendency for "regression to the mean". This means that when patients are recruited to studies with a low PI,max they are likely to have a higher one when retested.

WEINER et al. [18] have previously reported very striking improvements in exercise performance following inspiratory muscle training. In this issue of the ERJ WEINER et al. [19] now ask the question whether, after an initial 3 month course of inspiratory muscle training, maintenance training is beneficial. The initial training conferred an increase in the 6-min walk of $50-60 \mathrm{~m}$ but thereafter the control group deteriorated so that by 12 months values were close to those observed at baseline [19]. The study was carefully performed and the control group used an identical trainer that required generation of just $7 \mathrm{cmH}_{2} \mathrm{O}$. The message from this paper seems to be that maintenance training preserves the effects of inspiratory muscle training. Enthusiasts will seize on this as evidence that training should be continued, but sceptics will continue to wonder how it works. In our view a study that employs a nonvolitional technique, such as magnetic stimulation of the phrenic nerves, to assess the effect of inspiratory muscle training on diaphragm contractility is urgently needed.

\section{References}

*Royal Brompton Hospital and National Heart and Lung Institute,
${ }^{\#}$ Guy's Kings and St Thomas School of Medicine, Kings College Hospital, London, UK.

Correspondence: M.I. Polkey, Royal Brompton Hospital and National Heart \& Lung Institute, Fulham Road, London, SW3 6NP, UK. Fax: 44 2073518939. E-mail: m.polkey@rbh.nthames.nhs.uk
Leith DE, Bradley M. Ventilatory muscle strength and
endurance training. J Appl Physiol 1976; 41: 508-516.

2. Pauwels RA, Buist AS, Calverley PM, Jenkins CR, Hurd SS. 
Global strategy for the diagnosis, management, and prevention of chronic obstructive pulmonary disease. NHLBI/ WHO Global Initiative for Chronic Obstructive Lung Disease (GOLD) workshop summary. Am J Respir Crit Care Med 2001; 163: 1256-1276.

3. Sharp JT, Van Lith P, Nuchprayoo CV, Briney R, Johnson FN. The thorax in chronic obstructive lung disease. Am J Med 1968; 44: 39-46.

4. Byrd RB, Hyatt RE. Maximal respiratory pressures in chronic obstructive lung disease. Am Rev Respir Dis 1968; 98 : 848-856.

5. Polkey MI, Kyroussis D, Hamnegard C-H, Mills GH, Green M, Moxham J. Diaphragm strength in chronic obstructive pulmonary disease. Am J Respir Crit Care Med 1996; 154: $1310-1317$.

6. Similowski T, Yan S, Gauthier AP, Macklem PT, Bellemare F. Contractile properties of the human diaphragm during chronic hyperinflation. N Engl J Med 1991; 325: 917-923.

7. Polkey MI, Kyroussis D, Keilty SEJ, et al. Exhaustive treadmill exercise does not reduce twitch transdiaphragmatic pressure in patients with COPD. Am J Respir Crit Care Med 1995; 152: 959-964.

8. Polkey MI, Kyroussis D, Hamnegard C-H, et al. Diaphragm performance during maximal voluntary ventilation in chronic obstructive pulmonary disease. Am J Respir Crit Care Med 1997; 155: 642-648.

9. Laghi F, Cattapan SE, Jubran A, et al. Is weaning failure caused by low-frequency fatigue of the diaphragm? Am J Respir Crit Care Med 2003; 167: 120-127.

10. Levine S, Kaiser L, Leferovich J, Tikunov B. Cellular adaptations in the diaphragm in chronic obstructive pulmonary disease. N Engl J Med 1997; 337: 1799-1806.
11. Mercadier J-J, Schwartz K, Schiaffino S, et al. Myosin heavy chain gene expression changes in the diaphragm of patients with chronic lung hyperinflation. Am J Physiol (Lung Cell Mol Physiol) 1998; 274: L527-L534.

12. Levine S, Gregory $\mathrm{C}$, Nguyen $\mathrm{T}$, et al. Bioenergetic adaptation of individual human diaphragmatic myofibers to severe COPD. J Appl Physiol 2002; 92: 1205-1213.

13. Ribera F, N'Guessan B, Zoll J, et al. Mitochondrial electron transport chain function is enhanced in inspiratory muscles of patients with chronic obstructive pulmonary disease. $\mathrm{Am}$ $J$ Respir Crit Care Med 2003; 167: 873-879.

14. Hart N, Sylvester K, Ward S, Cramer D, Moxham J, Polkey MI. Evaluation of an inspiratory muscle trainer in healthy humans. Respir Med 2001; 95: 526-531.

15. Scherer TA, Spengler CM, Owassapian D, Imhof E, Boutellier U. Respiratory muscle endurance training in chronic obstructive pulmonary disease: impact on exercise capacity, dyspnea, and quality of life. Am J Respir Crit Care Med 2000; 162: 1709-1714.

16. Demoule A, Verin E, Derenne J-P, Similowski T. Plasticity of the human motor cortical representation of the diaphragm. Am J Respir Crit Care Med 2001; 163: A46.

17. Lotters F, van Tol B, Kwakkel G, Gosselink R. Effects of controlled inspiratory muscle training in patients with COPD: a meta-analysis. Eur Respir J 2002; 20: 570-576.

18. Weiner P, Azgad Y, Ganam R. Inspiratory muscle training combined with general exercise reconditioning in patients with COPD. Chest 1992; 102: 1351-1356.

19. Weiner P, Magadle R, Beckerman M, Weiner M, BerarYanay N. Maintenance of inspiratory muscle training in COPD patients: one year follow-up. Eur Respir J 2004; 23 : $61-65$. 